\title{
Born Violent: The Origins of Nuclear Power
}

\author{
Robert Jacobs
}

\begin{abstract}
This article traces the history of the development and construction of the first prototypes and operating nuclear power plants, all as part of the Manhattan Project. Beginning with CP-1, the first self-sustained nuclear chain reaction in 1942, it details subsequent Manhattan Project reactors and then examines the construction and operation of the first modern nuclear power plants built at Hanford, Washington. These were built for the sole purpose of manufacturing plutonium for nuclear weapons. The article argues that nuclear power was born violent: it was invented as part of the manufacturing process of nuclear weaponry. This argument goes beyond previous historiography focusing on the technological development of nuclear power to emphasize the purpose of its development, the mass and indiscriminate killing of human beings.
\end{abstract}

Keywords nuclear power, nuclear weapons, plutonium, Hanford, CP-1

\section{Introduction: Born to Kill}

On December 2, 1942 at the University of Chicago, a group of scientists and engineers produced an amazing technological achievement: a sustained nuclear chain reaction. Nuclear power was intentionally released in a controlled manner, adjusted, and then turned off. This experiment opened the doors for human beings to develop both nuclear power plants and nuclear weaponry. Indeed, both outcomes were a part of our world less than three years after that cold December day.

The team, working under Enrico Fermi, was confident that they would be able to effectively control the nuclear chain-reaction. However, they did take rudimentary safety precautions in case the reaction became uncontrolled, having neutron absorbing materials at the ready. Three million people lived in Chicago in December of 1942, and they had no idea history was being made that Wednesday in a rackets court under the stands of Stagg Field, the university's football stadium (rackets was an indoor sport popular in the United Kingdom that diminished in popularity after World War Two). Fortunately for all of them, 
the experiment proceeded as designed and these safety measures were unneeded. Within a year of the success of the experimental reactor, dubbed CP-1 for "Chicago Pile 1," the first model full reactor had been built and gone critical in Oak Ridge, Tennessee, and within two years the first industrial reactors built to mass produce plutonium - or plutonium production reactors - had been built at Hanford, Washington. Ultimately nine nuclear reactors would be built at Hanford which would manufacture the bulk of the plutonium found in the cores of America's Cold War nuclear arsenal.

All of these efforts were part of the Manhattan Engineering District, or as it came to be known: the Manhattan Project. While the specific scientific discoveries that had opened the door to releasing the energy held within the nuclei of atoms were achieved by small research teams working at universities, the large-scale engineering required to harness that energy was funded entirely by the U.S. military, with the sole purpose of building nuclear weapons. The nuclear power plants built at Hanford would operate for four decades, and were used almost exclusively to manufacture plutonium for weapons. It would be more than ten years from the initial criticality of Manhattan Project nuclear reactors before nuclear power plants would be used to manufacture electricity for use by the general public in any country. Generating electricity is a secondary purpose for this technology; it was invented to make nuclear weapons.

This article traces the origins of nuclear power technology as it was specifically developed to produce nuclear weapons for use against a civilian population in war. It will explore the scientific and industrial steps taken from the initial experiments in Germany and under the stands of Stagg Field in Chicago to develop the theoretical basis of nuclear energy production and subsequently of plutonium production, and then the industrial establishment of large nuclear power plants built at Hanford, Washington as a primary site of the sprawling Manhattan Project. It will trace numerous radiological disasters during the production history of the Hanford reactor fleet and at other military plutonium production reactor sites during the early Cold War. It will describe the later emergence of the nuclear power production industry which used nuclear reactors to also produce energy for civilian use and the history of partial and full nuclear fuel meltdowns that accompanied that industry.

The very first history of CP-1 and Hanford was the official history of the Manhattan Project published by Henry DeWolf Smyth (1945). Subsequent histories of the Manhattan Project described the experimental and production reactors as part of the story of the project, but with little focus beyond describing their role in the project. Scholarship about CP-1 has primarily been focused on the scientific basis and organization of the experiment. The best work on the technical aspects of these sites, and the Manhattan Project as a whole, is Critical Assembly written by Lillian Hoddeson and co-authors (Hoddeson et al. 2004). Since the end of the Cold War, site specific works on Hanford begin to 
be published, including On the Homefront by Michele Gerber (1992), Atomic Frontier Days by Findlay and Hevley (2011) and Atomic Geography by Melvin Adams (2016). Kate Brown's powerful comparison of the plutonium production sites of the United States and USSR at Hanford and Ozersk, respectively, titled Plutopia is one of the most important works that examines the legacies of plutonium production through the use of nuclear reactors to date (Brown 2013). Trisha Pritikin, who grew up in Richland, Washington, has written what will be the definitive history of the legal claims filed by Hanford downwinders seeking compensation for their loses of health and land from the radiological contamination inflicted on the downwind communities during the decades of plutonium production at the site (Pritikin, forthcoming).

These books do critical work in examining the establishment and operation of the Hanford site and of the radiological violence exerted on the local community. However, no work has traced back the fundamental violence of nuclear power plants: that they were first invented specifically to kill masses of human beings. Nuclear power plants were born violent.

\section{The Scientific Basis}

Scientists had known since the early twentieth century that there was incredible energy binding the nuclei of atoms together. Subatomic particle physicists would describe the universe as being made of up four fundamental forces: gravity, electromagnetism, the weak interaction, and the strong interaction. One of these, the strong interaction, or strong force as it was originally known, is the powerful energy that holds the nucleus together (Frisch 1961). Even as the structure of atoms was being parsed during the first decades of the twentieth century, the nucleus was seen as impenetrable until 1938 when the nucleus of a uranium isotope was split by a neutron in the lab of Otto Hahn in Berlin. Hahn had been conducting experiments with the physicist Lise Meitner, who had fled from Germany earlier in the year to escape Nazi prosecution. After Hahn and his assistant Fritz Strassmann obtained unusual results from a series of experiments Hahn shared these results in a letter with Meitner. Meitner speculated on the lab results obtained by Hahn and, with her nephew Otto Frisch, theorized that what had occurred had been the fissioning of the nuclei of some of the uranium atoms being used (ibid.). What had happened in Hahn's lab was that by bombarding uranium atoms with neutrons, the nuclei of some number of the atoms had split, releasing the energy of the strong force contained within. News of the amazing discovery quickly spread throughout the physics world.

In the United States, where many prominent scientists from Europe had fled to escape Nazi persecution, this breakthrough led to a flurry of experimentation to replicate and extend Hahn's findings. Among the scientists engaged in this 
work was Hungarian Leo Szilard, working at the time at Columbia University. Szilard had theorized the possibility of a weapon utilizing the energy locked in the nucleus while in London in 1933. Upon learning of Hahn's discovery, Szilard sought to press upon the U.S. government the risk of such a weapon being developed by the Nazis. Szilard famously pressed upon his friend Albert Einstein to convey a letter regarding this possibility to American President Franklin Roosevelt, and the Manhattan Project was soon initiated (Lanouette 1992).

Among the challenges for the Manhattan Project was how to produce sufficient fissionable material to achieve a nuclear explosion. Subsequent to Hahn's work, experiments determined that it was a rare isotope of uranium $-{ }^{235} \mathrm{U}$ - that fissioned. Raw uranium mined from the Earth contains less than 1 percent of this isotope; other uranium isotopes did not fission. One possibility to make a bomb was to enrich uranium until a high concentration of ${ }^{235} \mathrm{U}$ was obtained. Another possibility was to use plutonium. Plutonium had been "invented" by a team led by Glenn Seaborg in a laboratory at the University of California in late $1940 .{ }^{1}$ One isotope of plutonium, ${ }^{239} \mathrm{Pu}$, could also fission if bombarded by neutrons.

Another primary challenge was to determine if a chain-reaction in a fissionable material was possible. Since the fissioned nuclei of ${ }^{235} \mathrm{U}$ and of ${ }^{239} \mathrm{Pu}$ gave off from one to three neutrons when fissioned, in was theoretically possible to split the nucleus of an atom with a neutron, and then when multiple neutrons were cast off by the reaction, to have more fissionable atoms packed close enough to the reaction to fission several more nuclei. Theoretically, one could initiate a process whereby fissioning some atoms, they would fission even more atoms and a chain reaction could be obtained. These challenges would structure some of the key installations and scientific endeavors of the Manhattan Project. A critical first step was to determine if a chain reaction could be achieved.

\section{CP-1: The First Chain Reaction}

Scientists at the University of Chicago, working under physicist Enrico Fermi, achieved the first self-sustaining chain reaction on December 2, 1942. The experiment consisted of the construction and operation of the first atomic "pile" until it had achieved criticality.

The pile itself was constructed of uranium, a material that is embedded in a matrix of graphite. With sufficient uranium in the pile, the few neutrons emitted in a single fission that may accidentally occur strike neighboring atoms, which in turn undergo fission and produce more neutrons. These bombard other atoms and so on at an increasing rate until the atomic 'fire' is going full blast. The atomic pile is controlled and prevented from burning itself to complete destruction by cadmium rods, which absorb neutrons and stop the bombardment process" (Fermi 1952, 23). 
Figure 1. The Only Photograph Taken during the Construction of CP-1

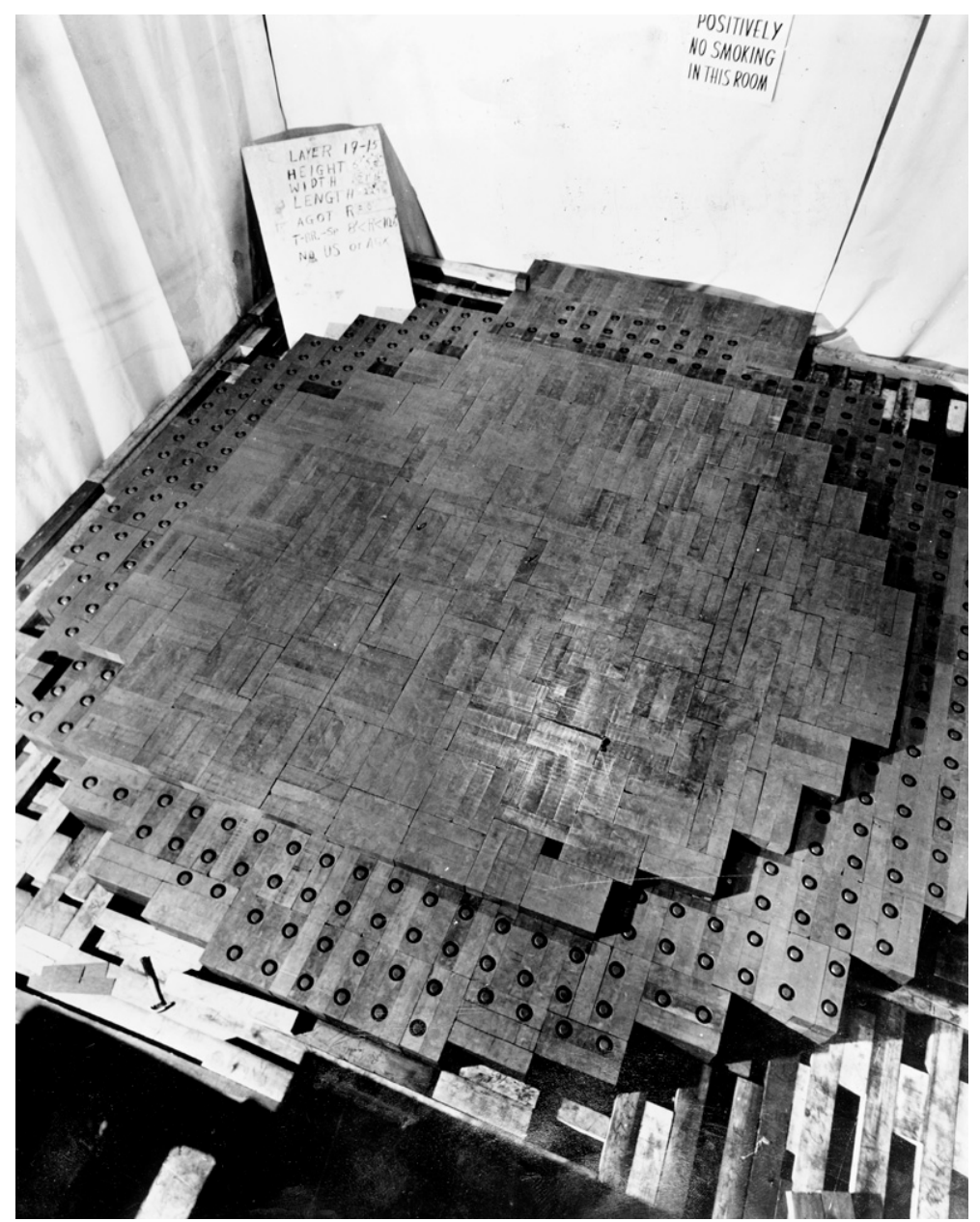

Source: U.S. Department of Energy

The pile was assembled throughout November 1942 in a rackets court underneath the stands of Stagg Field, a football field on the campus of the University of Chicago, and was referred to as Chicago Pile 1, or CP-1. Over 400 tons of graphite, 6 tons of uranium metal, and 50 tons of uranium oxide were configured into a large rectangular structure in a precise pattern designed by Fermi and his team (Hewlett and Anderson 1962). On December 2 the pile achieved criticality and was the first self-sustaining nuclear chain reaction created by human beings.

The experiment proved that it was possible to control the release of energy from nuclear sources in a controlled and sustainable manner. The nuclear power 
plants that would follow this event would not simply scale up the CP-1 design, they would ultimately augment and modify the configuration to more efficient standards, but it was on December 2, 1942, in that rackets court at Stagg Field, that human control over nuclear energy was midwifed. Both nuclear power and nuclear weapons are directly descended from this event, but the goal was unambiguous to those participating in the experiment. Warren Nyer, a young physicist on Fermi's team who would go on to work on reactor development at the Idaho National Laboratory, remembers of the understanding among those in the rackets court on that Wednesday: "There were two things that might follow, nuclear power for civilian purposes, or, what was really the purpose at that time, a nuclear weapon" (Argonne 2012).

Following the experiment, CP-1 was disassembled in early 1943 and moved to the nearby Argonne Forest Preserve, a site that would become Argonne National Laboratory in 1944, where it was reassembled with modifications and operated under the name CP-2 until it was decommissioned in 1954. After the nuclear material was removed from CP-2, it was buried in the Cook County Forest Preserve in an area known as Red Gate Woods, where it remains today (Forest Preserves of Cook County, n.d.).

\section{CP-3 and the X-10 Graphite Reactor}

"The immediate objective of building a uranium-graphite pile," wrote Henry Smyth in the first official history of the Manhattan Project, "was to prove that there were conditions under which a chain reaction would occur, but the ultimate objective of the laboratory was to produce plutonium by a chain reaction" (Smyth 1945, 99). Several reactor prototypes were subsequently envisioned and constructed to inform the design of the nuclear power plants that were to be built at Hanford. These included CP-3, built at Argonne, and the X-10 Graphite Reactor, built at the Clinton Engineer Works in Tennessee which would become Oak Ridge National Laboratory.

CP-3 was the first heavy water reactor ever built and was "designed and built as an alternative design for the Hanford project, in case unforeseen difficulties should arise when the Hanford plant went into operation," because, "there was a possibility that graphite moderated nuclear reactors could not produce the fissionable material required for the Manhattan Project program" (Nuclear Engineering Division, n.d., 13). The Argonne site, known in the Manhattan Project as Site A, became the first nuclear reactor site to generate sufficient radioactive waste to require a disposal site, which became known as Plot $\mathrm{M}$ at Red Gate Woods. "Plot M was a 150-foot by 140 -foot area approximately 1,500 feet north of Site A. The 1940s method of nuclear-waste disposal consisted of digging a 6-foot-deep trench, dumping the waste, and backfilling the trench with 
Figure 2. CP-3 Burial Site in Plot M at Red Gates Woods "Site A" of the Forest Preserves of Cook County

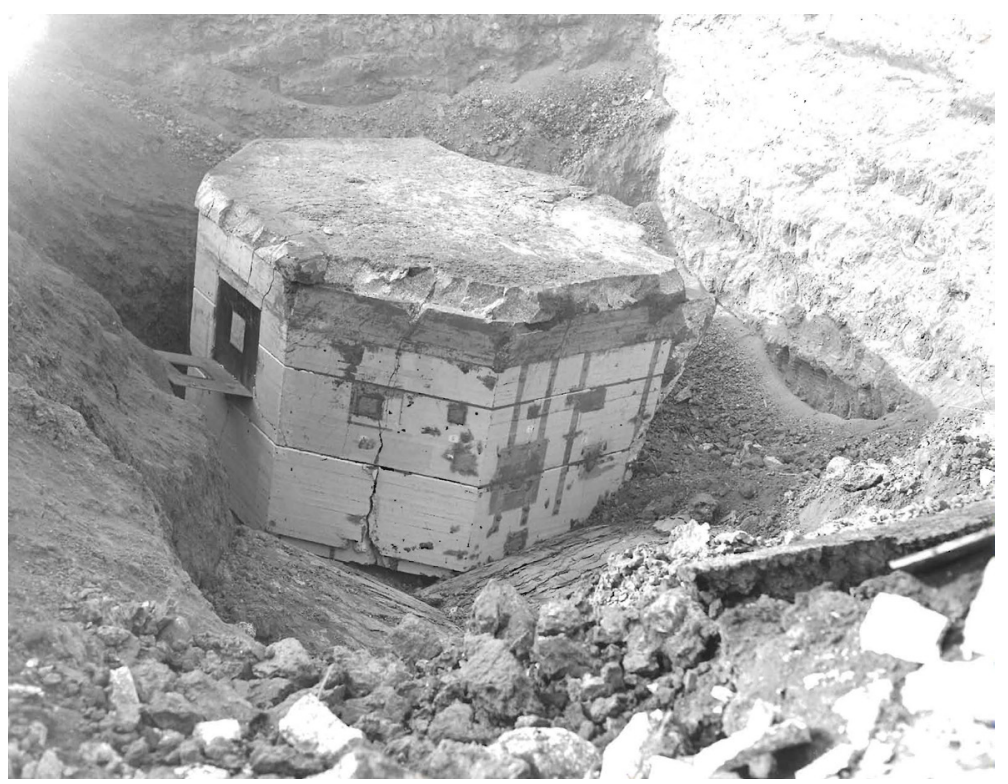

Source: U.S. Department of Energy

soil" (USDOE 2017, 2). The most dangerous waste would later be dug up and shipped on to other U.S. government sites for disposal.

The X-10 graphite reactor, also known as the Clinton Pile, was a variation of CP-1 and was aimed at determining an efficient design for plutonium production and extraction. The pile would need large amounts of electricity and was, in part, sited in Tennessee because of the copious production of electricity from the Tennessee Valley Authority construction during the New Deal. It was intended that the X-10 reactor would be used for training and development purposes to help improve the design and operation of the reactors being built at Hanford. Along with the graphite reactor, the Clinton Works also contained the first industrial sized plutonium separation facility. The X-10 reactor achieved criticality in November 1943, by March 1944 it was producing significant quantities of plutonium, and by the summer quantities of plutonium were being shipped to Los Alamos for experimental purposes (Hewlett and Anderson 1962). Oak Ridge was the location where uranium was enriched sufficiently for it to be used in the core of nuclear weapons. 


\section{Hanford during the Manhattan Project}

Fermi's pile in Chicago was an essential step in the achievement of industrial level nuclear power plants, but such plans did not wait or hinge on its results. On the day before the success of CP-1, Manhattan Project military head General Leslie Groves had formally authorized the construction of nuclear reactors for plutonium production at Hanford (ibid.). The site was originally referred to as Site W and was eventually known as the Hanford Engineer Works (Sanger 1989). The specific location was chosen because of the abundance of two essential ingredients for operating nuclear power plants: water and electricity. The water came from the nearby Columbia River; Site W was built in the Columbia Basin as it turned 90 degrees to flow westward towards the Pacific Ocean. The electricity came from the recently completed Bonneville Dam located further downriver in the Columbia Gorge (Harvey 2000). The plants were built and operated as a plutonium production facility by the chemical giant E.I. du Pont de Nemours \& Company on behalf of the U.S. government (Sanger 1989).

The first nuclear reactor built at Hanford was the B Reactor. Construction began in March 1943, as did construction of facilities for the workers. Three reactors would be built and operated during the Manhattan Project period, with the D Reactor and F Reactor following the B Reactor. All three were graphite moderated and water-cooled reactors (Gerber 1992).

As the purpose of the entire facility was the production of plutonium, four

Figure 3. Construction of the B Reactor at Hanford, 1944

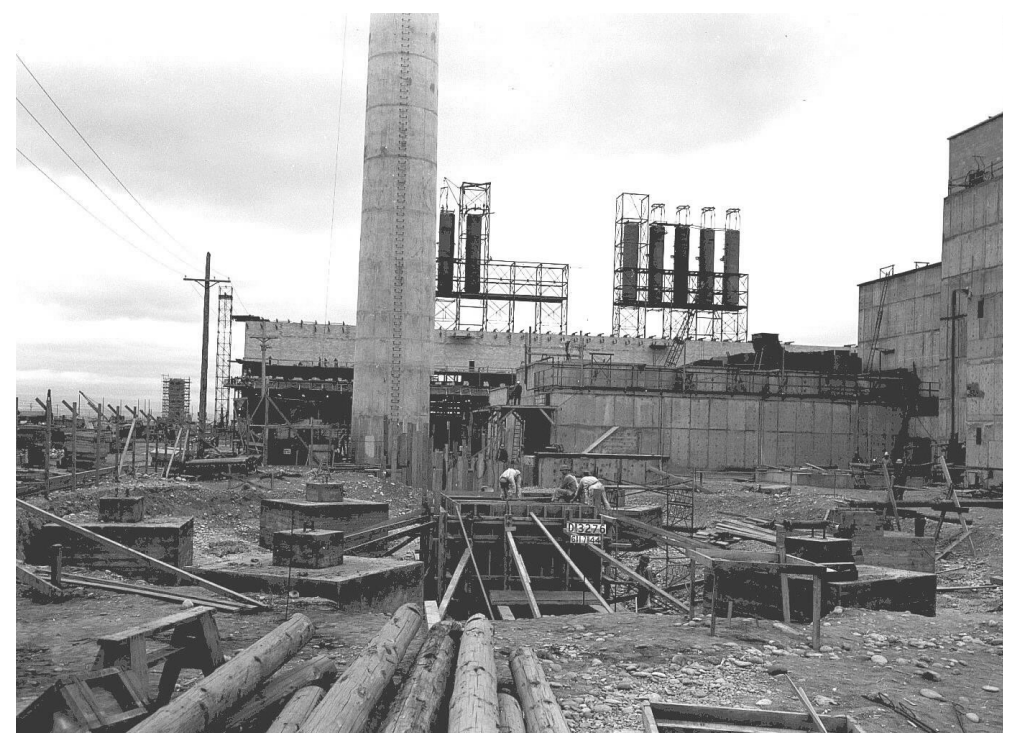

Source: U.S. Department of Energy 
chemical separation plants were built during the wartime period to process the spent fuel rods of the three reactors. The first shipment of plutonium was finalized in late January 1945, after which regular shipments of plutonium were sent from Hanford to the laboratory in Los Alamos. The plutonium was transported to Los Alamos by truck, with each shipment accompanied by radio equipped cars filled with armed guards (Hewlett and Anderson 1962).

The wartime construction of Hanford was unprecedented for a previously undeveloped site:

Army engineers and DuPont's TNX Division, a division created specifically for HEW [Hanford Engineer Works] construction built over five hundred structures in addition to those for living requirements. Workers laid 158 miles of railroad and 386 miles of automobile roadway. Over 50 miles of electrical transmission lines and four step-down substations were constructed. Hundreds of miles of fencing were emplaced, and 40,000 tons of structural steel and 780,000 cubic yards of concrete were utilized. During 1944 and early 1945, a peak of about 50,000 construction workers were housed at a barracks and trailer camp at the old Hanford townsite. The wartime construction of Hanford cost about \$230 million (Gerber 1992, 35-36).

The water consumption for the three reactors operating during the war would equal the requirements of a city with a population of a million people (Hewlett and Anderson 1962).

Three cities were built to accommodate the workforce and their families: Richland for management, Kennewick and Pasco for laborers and support workers. While originally these towns were assembled as temporary accommodations, eventually each became a coherent and independent city, although the region was and is still known as the Tri-Cities area. DuPont's internal company history assessed that over 140,000 workers passed through Hanford during the Manhattan Project era (Sanger 1989).

The scientists at Los Alamos came up with two different designs for nuclear weapons: the gun design (which was envisioned since the beginning of the project), and the implosion design. Ultimately both would be built. The gun design weapon was built with the highly enriched ${ }^{235} \mathrm{U}$ that was manufactured at Oak Ridge, and was then used in the nuclear attack on Hiroshima. The much more complex implosion design was built with the plutonium manufactured at Hanford, and was detonated twice in the summer of 1945: first at the Trinity Test in New Mexico (the first nuclear weapon detonation on Earth), and subsequently in the weapon used in the nuclear attack on Nagasaki. Each of the weapons used in the nuclear attacks would ultimately claim over 100,000 lives, most of these on the days of the nuclear attacks. 


\section{Hanford during the Cold War}

After the end of war, Hanford would come to manufacture most of the plutonium that would form the cores of the more than 60,000 nuclear weapons built by the United States during the Cold War, with some additional production coming from the Savannah River Site in South Carolina. As the Cold War intensified, so too did the work of the nuclear reactors and plutonium separation facilities at Hanford. The H Reactor would be built in 1949, and four more reactors would come online in the 1950s. The final reactor, the N Reactor would be built in 1963 . Five reprocessing plants for plutonium separation would eventually be built in two locations on the reservation. The four reactors built in haste in the 1950s can be seen as a direct response to the Soviet acquisition of nuclear weapons in 1949, and as an embodiment of the arms race for the United States, which was to a large extent predicated on levels of plutonium production in the military reactor fleets of both the United States and the Soviet Union.

The fleet of reactors stretched along the bend of the Columbia River operated continuously, except during brief periods of refueling, for decades. While ultimately there would be nine nuclear reactors at Hanford, only the final reactor, the $\mathrm{N}$ Reactor, ever contributed electricity to civilian power usage (the $\mathrm{N}$ Reactor was still primarily a plutonium production reactor). During the height of the Cold War, from 1961 to 1963, American plutonium production peaked at 7.5 tons per year (Cochran, Arkin, and Norris 1988). In total, Hanford produced

Figure 4. Nuclear Reactors Stretch along the Columbia River at Hanford in 1960

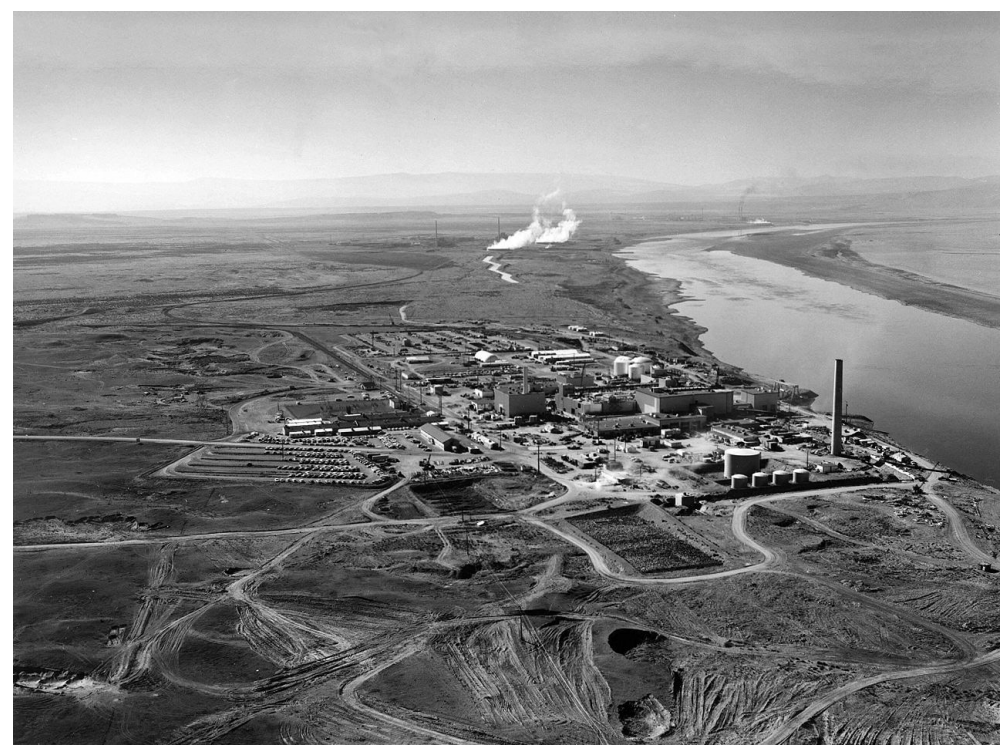

Source: U.S. Department of Energy 
49.1 metric tons of plutonium in the eight reactors dedicated to weapons grade plutonium production, and produced another 8.1 metric tons of fuel-grade plutonium at the N Reactor (Makhijani et al. 1995).

During the Cold War, the United States produced over 60,000 nuclear weapons, most of them with the plutonium produced at Hanford. This includes both fission weapons like the one used in the nuclear attack on Nagasaki, and also in thermonuclear weapons. While nuclear weapons were not used in warfare after 1945, over 2,000 weapons have been detonated in nuclear tests, roughly half of those $(1,054)$ by the United States. The United States tested 928 nuclear weapons at the Nevada Test Site, and another 67 at the Pacific Proving Grounds in the Marshall Islands. Two hundred and sixteen of those tests were in the atmosphere, which distributed vast quantities of radioactive fallout in heavy quantities close to the test sites, and also globally when the atmospheric clouds reached the upper atmosphere. A 2015 article in The Lancet describes how "risk modelling studies of exposure to ionising radiation from the Nevada Test Site in the United States suggest that an extra 49,000 (95 percent CI 11 300-212 000) cases of thyroid cancer would be expected to occur among U.S. residents alive at the time of the testing-an excess of about 12 percent over the 400,000 cases of thyroid cancer expected to develop in the absence of fallout" (Simon and Bouville 2015, 407-408). The Marshall Islands had far fewer tests than the Nevada test site, however the United States tested its thermonuclear weapons exclusively at the Pacific Proving Ground which resulted in massive amounts of radioactive fallout affecting the local population and also entering into the Pacific Ocean from which the radionuclides could disperse throughout the Pacific Rim.

One test, the Bravo test of 1954, which was the largest weapon ever tested by the United States, created a vast and lethal fallout cloud that engulfed numerous Marshallese atolls. The entire population of Rongelap Atoll suffered from radiation sickness after the Bravo test. The Japanese tuna fishing boat the Daigo Fukuryu Maru, among many others, was also exposed to the fallout cloud. When it came to port in Yaizu, Japan two weeks after the test, its crew was hospitalized for radiation sickness. One crew member, radioman Aikichi Kuboyama, died of complications from his exposure six months later, even though he was physically located about $100 \mathrm{~km}$ from the actual detonation point. All of these illnesses and deaths can be traced back to the nuclear reactors at Hanford.

During its years of production, Hanford was the site of numerous substantial radiological releases that endangered the local population as well as those downwind. Among the most grievous was the notorious Green Run conducted in late 1949. The Green Run was a planned experiment to facilitate the monitoring and assessment of the nascent Soviet plutonium production capabilities. While plutonium production had been rushed during the Manhattan Project, after the war the spent nuclear fuel was typically "cooled" before the plutonium was extracted from the fuel rods. "After discharge from the Hanford reactors, the 
irradiated nuclear fuel was normally stored for many weeks before processing," describes a Fact Sheet published by the Technical Steering Panel of the Hanford Environmental Dose Reconstruction Project. "This 'cooling the fuel' delay allowed short-lived radioactivity to decay. The cooled fuel was dissolved in nitric acid and the solution processed to separate the plutonium" (Technical Steering Panel 1992, 1). The practice specifically minimized the distribution of ${ }^{131} \mathrm{I}(\mathrm{a}$ radioactive isotope of iodine) as well as to decrease the risks to the workers from short-lived radionuclides. This was done, in part, because the United States had a stockpile of plutonium and did not urgently need the material as it had during wartime. Once the Soviet Union had built and tested its own nuclear weapons earlier in the autumn of 1949, the United States became frantic to assess the plutonium production of the Soviet Union to gauge its capacity to build up a nuclear arsenal.

The Green Run was designed to process a batch of fuel rods for plutonium extraction before the "cooling" period. Historian Kate Brown $(2013,169)$ writes, "The experiment called for processing a ton of twenty-day 'green' fuel and tracking its distribution across the Columbia Basin...If Air Force officers could find out how much short-lived radioactive iodine came out of the ton of green fuel, they could estimate from monitoring the air on the borders of the USSR how much plutonium the Soviets were making." To facilitate the experiment, the filters in the discharge stacks of the processing plant were turned off. The Green Run, which a U.S. Government Accounting Office report later described as an "atomic energy intelligence collection experiment" would ultimately release as much as 12,000 curies of radioiodine and contaminate a vast area downwind: "after the test, radioactive iodine was found on vegetation over large areas of southeast Washington and Oregon" (Government Accounting Office 1993, 6-7). Hanford scientists would later point out that although the Green Run was a radiological disaster, it distributed significantly less radioiodine than was routinely released during the Manhattan Project era, "the amount of material being dissolved was, I think, smaller than normal. This was just a batch that had been fixed up particularly for them. When the reactors had run originally-when the military was very, very interested on getting their hands on plutonium-they put out a lot more than was put out in the Green Run" explained health physicist Carl Gamertsfelder (Gamertsfelder 1995).

Large releases of radiation into the nearby ecosystem would be routine during the operation of the Hanford reactors and especially the plutonium extraction procedures. These activities would leave a disastrous legacy once the plants were closed. As more and more information became public after the closure of the site, there was a growing awareness in the community that exposures to radiation had been far more extensive than previously designed and had occurred over a long time period. Numerous studies of these impacts were commissioned by various governmental bodies. 
In 1986, the Hanford Health Effects Review Panel, convened by the Centers for Disease Control at the request of the Washington State Nuclear Waste Board and the Indian Health Service, recommended that potential doses from radioactive releases at Hanford be reconstructed. The states of Oregon and Washington, representatives of three regional Indian tribes, and DOE [Department of Energy] agreed that an independent technical steering panel (TSP) should direct the HEDR Project [Hanford Environmental Dose Reconstruction Project], which is managed and conducted by the Pacific Northwest Laboratory (Haerer et al. 1990).

Additionally, a Hanford Thyroid Disease Study was mandated by Congress in 1988 (Davis, Kopecky, and Hamilton 2002). These studies would document broad public exposure to radiation resulting from the operation of the Hanford site over many decades, extending far beyond the borders of the facility and the specific personnel employed there.

The B Reactor was decommissioned in 1968; other reactors were decommissioned during the next two decades with the final reactor, the $\mathrm{N}$ Reactor, being decommissioned in 1987.

\section{Hanford's Radiological Legacy}

In 1989, two years after the decommission of the last of the Hanford nuclear plants, the U.S. Environmental Protection Agency identified between 1,200 and 1,500 sites where toxic materials had been dumped on the Hanford reservation (Schneider 1989). Very few of these have been monitored. A dramatic example is the PUREX tunnels, where a significant collapse occurred in 2017. During its normal operation, spent fuel rods were transported from reactors to chemical separation facilities by rail cars that were operated remotely because of the intensely high levels of gamma radiation coming from the rods. When production ceased, the highly radioactive rail cars that had performed this task were loaded with contaminated equipment and buried in tunnels, the PUREX tunnels. These were then abandoned and had little ongoing monitoring, as the radiation was largely inert, coming from the irradiated equipment, and posed little threat of migration. In May 2017, one of the PUREX tunnels collapsed. The day of the collapse is uncertain as there was no ongoing monitoring of the tunnels; it was discovered by workers on May 7 (Cary 2017).

Far more vexing than the abandoned waste dumping sites is the Tank Farm, a site encompassing 177 underground tanks containing a mix of highly radioactive waste and toxic chemicals. One hundred and forty-nine of the tanks were singleshelled, having only one wall containing the waste, and twenty-eight later tanks were double-shelled (Edgemon et al. 2009). The tanks are actively monitored twenty-four hours a day, and toxic fumes leaking from the tanks has resulted in the hospitalization of over seventy workers per year for the past several years. 
Figure 5. Construction of Nuclear Waste Storage Tanks at Hanford, 1943

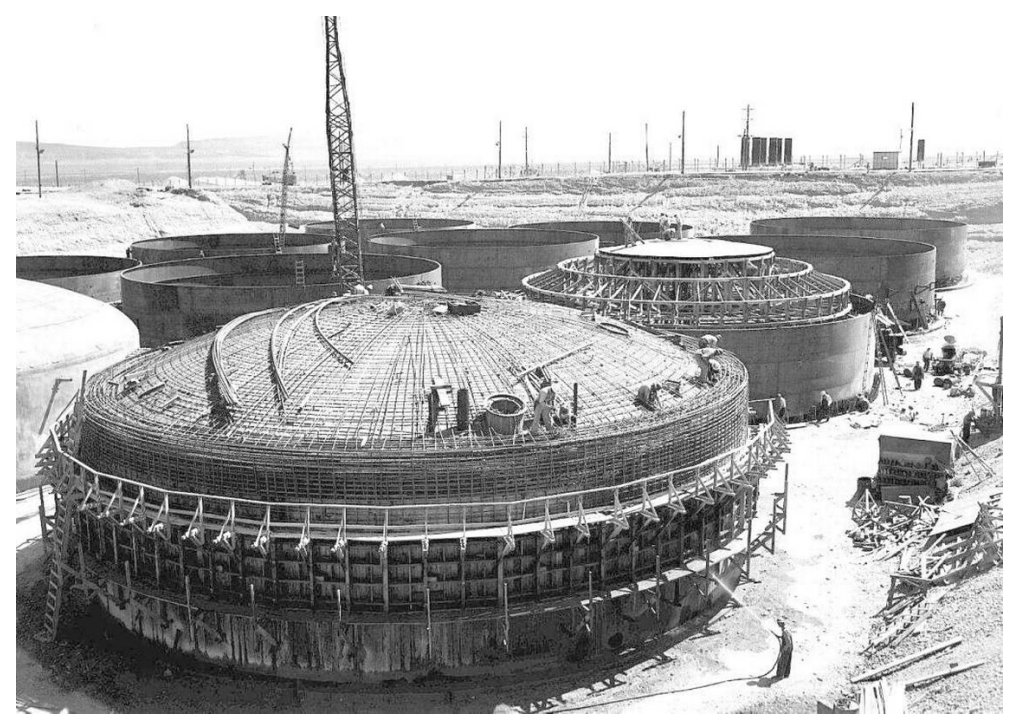

Source: U.S. Department of Energy

The tanks contain over 53 million gallons of radioactive and chemically toxic waste, and a substantial number of the tanks have been leaking for decades. The U.S. Department of Energy, which oversees the site, estimates that over 1 million gallons of waste has leaked from the tanks and is migrating underground towards the nearby Columbia River (Committee on Remediation of Buried and Tank Wastes 1996).

Today, seventy-five years since production began at Hanford, and over thirty years after production ceased, the site is a maze of ecological disasters and mismanagement. Vast quantities of waste await the development of technologies that are envisioned to contain them. The worst of this waste is being actively managed but not efficiently contained, and even the workforce that is engaged in these efforts is at risk. The budgets required to strategize and approach these challenges are being slashed from administration to administration. Politics is hardly adequate to grapple with millennia long risks. A proposal by the U.S. Department of Energy, which oversees the legacy waste clean-up of the U.S. nuclear weapon complex-including Hanford-envisioned reclassifying some high-level waste as low-level waste in December 2018. This would include the waste in the Tank Farm at Hanford. If such a policy were implemented the waste in the tanks would no longer have to be removed from the leaking tanks and permanently contained; it could simply be capped with concrete and left in the tanks to leak. A USDOE spokesperson explained "the change could save the federal government $\$ 40$ billion in cleanup costs across the nation's entire nuclear 
weapons complex, which includes the Savannah River Plant in South Carolina and Idaho National Laboratory" (Geranios 2018).

\section{Historical Disasters at Plutonium Production Sites}

Hanford did not suffer a major fuel meltdown or catastrophic fire. However, all other nuclear weapon states have also operated multiple plutonium production reactors and the first two large-scale nuclear disasters occurred in such reactor complexes, happening within two weeks of each other.

On September 29, 1957, writes Kate Brown, as a soccer game was being played in a stadium in Ozersk, in the Chelyabinsk Oblast near the Ural Mountains in Central Russia, where the Mayak Production Association was located, a loud explosion was heard nearby.

The source of the blast was an underground storage tank holding highly radioactive waste that overheated and blew, belching up a 160-ton cement cap buried twenty-four feet below the ground and tossing it seventy-five feet in the air. The blast smashed windows in the nearby barracks and tore the metal gates off the perimeter fence. A column of radioactive dust and smoke rocketed skyward a half mile (Brown 2013, 232).

The explosion and subsequent radiological disaster, known as the Kyshtym Disaster, occurred just eight years and one month after the detonation of the first Soviet nuclear weapon made with plutonium produced at Mayak, the plutonium production that was the target of surveillance motivating the Green Run at Hanford.

The radioactive cloud from the explosion, "settled over an area of 20,000 square kilometers, home to 270,000 people” (Rabl 2012). The Soviet authorities were slow to react to the crisis. "A week after the explosion," writes Brown, who did extensive fieldwork in the region as well as at Hanford, "radiologists followed the cloud to the downwind villages, where they found people living normally, children playing barefoot. They measured the ground, farm tools, animals and people. The levels of radioactivity were astonishingly high" (Brown 2013, 239240). The contaminated area would eventually be known as the East Urals Radioactive Trace (Ichikawa 2015).

Eleven days later a fire ignited in one of the reactors at the Windscale Works, the plutonium production site of the United Kingdom located in Cumbria in Northwest England. The fire burned inside of the reactor for three days and released massive amounts of radiation blanketing surrounding communities and downwind areas. "While the authorities denied large releases of radioactivity at the time, this was not a correct portrayal of the situation... On 12 October, 
authorities stopped the distribution of milk originating from seventeen area farms. However, just three days later, milk from a far wider area (200 square miles compared to the previous 80) was restricted" (Makhijani et al. 1995, 418). Fallout from the accident was detected in Ireland, and the confiscated milk was dumped into the Irish Sea (Bertell 1985).

\section{The Establishment of Commercial Nuclear Power}

While the promise of commercial nuclear power was promoted to the public immediately after World War Two, it would not happen for almost a decade. The first experimental plant to actually produce a miniscule quantity of electricity was the X-10 reactor at Oak Ridge in 1948. However, the Experimental Breeder Reactor at the Idaho National Laboratory produced enough electricity to illuminate four light bulbs in 1951. The first nuclear power plant to contribute electricity to the grid for public usage was built in the former Soviet Union. In 1954, the Obninsk Nuclear Power Plant, in the city of Obninsk southwest of Moscow, came online for power generation purposes, and not for plutonium production. In 1956, Calder Hall-A came online in the United Kingdom, operating alongside the two plutonium production reactors located at Windscale. In 1957, the Shippingport Atomic Power Station on the Ohio River in Pennsylvania achieved criticality and began to feed power into the U.S. grid. Commercial plants would follow in France (1962) and Canada (1968); ultimately 450 commercial nuclear power plants would be operating in 31 countries by 2016 (European Nuclear Society, n.d.).

Many of these plants would experience occasional leaks or releases of radiation into their local ecosystems. Several would have catastrophic nuclear accidents. In addition to the accidents at plutonium production reactors cited above, partial core meltdowns would occur at Santa Susana in Simi Valley, California (1957), Fermi-1 in Detroit, Michigan (1966), the Lucens reactor in Vaud, Switzerland (1969), Leningrad-1 in Leningrad, USSR (1975), and Three Mile Island-2 in Harrisburg, Pennsylvania (1979). A full, catastrophic nuclear meltdown occurred at Chernobyl-4 (1986) and three full meltdowns occurred at Fukushima 1-2-3 in 2011.

In addition to these dire nuclear accidents, the spent fuel from normal operations at nuclear power plants pose a vexing problem for tens of thousands of generations. These spent fuel rods will need to be effectively contained for millennia as they will remain highly dangerous for over 10,000 years, and seriously dangerous for over 100,000 years. Almost all of this spent fuel, millions of tons, sit in temporary or intermediate storage on the grounds of the reactors where the fuel was burned. Finland will be the very first nation to attempt to permanently store the spent fuel from its very limited nuclear power program 
Figure 6. Calder Hall \#1 at the Windscale Site in Cumbria, UK

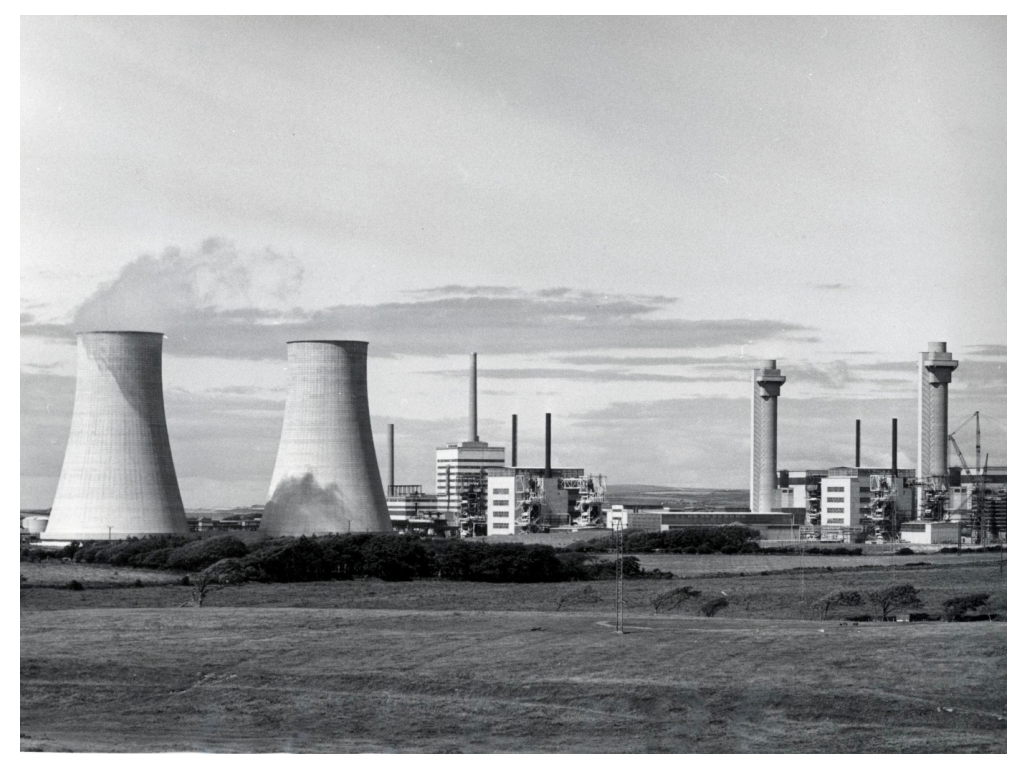

Source: U.S. Department of Energy

in deep geological storage at the Onkalo site on the Baltic Sea, beginning in the 2020s. All of the spent nuclear fuel from the long history of operation at Hanford still sits in temporary storage, some of it for over seventy years now (Defense Nuclear Facilities Safety Board 1997). The challenges of containing this highly toxic waste for millennia and insuring that the sites are not damaged by geological forces or breached by future human societies is speculative at best. The ongoing capacity of nuclear power to damage the health of human beings and other creatures for millennia, through the risks posed by this waste, means that we can never adequately grasp the full violence that will result from its production (Jacobs 2018). To date, over seventy years after the successful operation of CP-1, not one spent fuel rod has been placed in "permanent" storage anywhere on the planet.

\section{Conclusion}

All nuclear weapon states begin their weapon programs by building and operating nuclear power plants. Any nation with nuclear power can proceed towards building nuclear weapons; if they have not pursued weapons it is because they have taken a political decision, for whatever reason, not to build them. It is possible to operate nuclear power plants without building nuclear weapons, but no nation has yet manufactured such weapons without first operating nuclear power plants. 
Figure 7. Chinzei Middle School, Nagasaki 1945

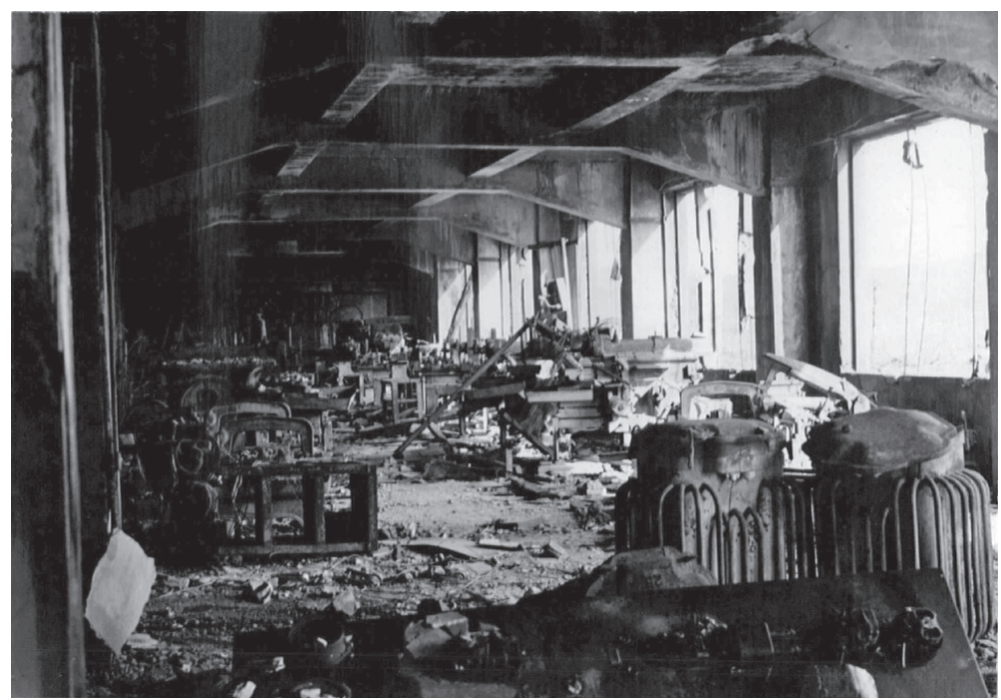

Source: United States Strategic Bombing Survey

Whatever its history was to become, however it was later utilized, the very first nuclear power plant was built specifically to kill 100,000 people-a goal that was efficiently and fully realized. Nuclear power was born violent: it was born as a fundamental element of a program designed to manufacture weapons of mass destruction. The expanded plutonium production sites of the nuclear weapon states sustained an ongoing potential through nuclear weapon arsenals to kill hundreds of millions more during the Cold War and beyond.

The violence of nuclear power plants is not limited to their use in manufacturing nuclear weapons. Nuclear meltdowns have caused the early deaths and the illness of untold thousands more. The number of deaths resulting from the Chernobyl disaster alone are bitterly contested, in part, because illnesses caused by internalized radionuclides rarely lead to direct and provable causation. Any visit to the communities surrounding the Chernobyl exclusion zone in both Belarus and the Ukraine makes the public health impacts obvious. The health impact of the triple meltdowns at Fukushima Daiichi continues to unfold before us.

Beyond the visible, nuclear waste may kill and harm for tens of thousands of years to come. Hundreds of thousands of tons of spent nuclear fuel rods will remain deadly for over 100,000 years and must be successfully contained for that entire period of time to protect the health of thousands of generations of humans and other creatures yet unborn. Nuclear power will remain violent long past the generation of any electricity that will benefit any being. The legacy waste of operating nuclear power plants-for weapons or for electricity-will remain 
dangerous for longer than human civilization has so far existed.

\section{Notes}

1. I bracket the term "invented" since plutonium does exist in nature-in the miniscule amount of ${ }^{235} \mathrm{U}$ that has fissioned naturally_but it was unknown to humans at the time it was isolated in the lab by Seaborg.

\section{References}

Adams, Melvin R. 2016. Atomic Geography: A Personal History of the Hanford Nuclear Reservation. Pullman, WA: Washington State University Press.

Argonne National Laboratory. 2012. “Argonne Nuclear Pioneers: Chicago Pile 1.” https:// youtu.be/0tKf7R2XncM (accessed November 15, 2018).

Bertell, Rosalie. 1985. No Immediate Danger: Prognosis for a Radioactive Earth. London: The Women's Press.

Brown, Kate. 2013. Plutopia: Nuclear Families, Atomic Cities, and the Great Soviet and American Plutonium Disasters. Oxford: Oxford University Press.

Cary, Annette. 2017. "Hanford Waste Tunnel Collapses, No Airborne Radiation Detected." Tri-City Herald, May 10. https://www.tri-cityherald.com/news/local/hanford/ article149475209.html (accessed November 13, 2018).

Cochran, Thomas B., William M. Arkin, and Robert S. Norris. 1988. "U.S. Nuclear Weapons Production: An Overview." The Bulletin of the Atomic Scientists 44 (1): 1216.

Committee on Remediation of Buried and Tank Wastes. 1996. The Hanford Tanks: Environmental Impacts and Policy Choices. Board on Radioactive Waste Management Commission on Geosciences, Environment, and Resources National Research Council. Washington DC: National Academy Press.

Davis, Scott, Kenneth J. Kopecky, and Thomas E. Hamilton. 2002. The Hanford Thyroid Disease Study Final Report. Seattle, WA: Fred Hutchinson Cancer Research Center.

Defense Nuclear Facilities Safety Board. 1997. Review of Hanford Spent Nuclear Fuel Project. Washington DC: Defense Nuclear Facilities Safety Board.

Edgemon, G. L., V. S. Anda, H. S. Berman, M. E. Johnson, and K. D. Boomer. 2009. "History and Operations of Hanford High-Level Waste Storage Tanks." Corrosion: The Journal of Science and Engineering 65 (3): 163-174.

European Nuclear Society. n.d. "Nuclear Power Plants Worldwide." https://www. euronuclear.org/info/encyclopedia/n/nuclear-power-plant-world-wide.htm (accessed November 21, 2018).

Fermi, Enrico. 1982. “Fermi’s Own Story." Chicago Sun Times, November 23. Reprinted in, Department of Energy. 1982. The First Reactor: $40^{\text {th }}$ Anniversary. Washington DC: United States Department of Energy.

Findlay, John M., and Bruce W. Hevley. 2011. Atomic Frontier Days: Hanford and the American West. Seattle: University of Washington Press. 
Forest Preserves of Cook County. n.d. "Red Gate Woods: 'Site A.” http://fpdcc.com/site-a/ (accessed November 15, 2018).

Frisch, Otto R. 1961. Atomic Physics Today. New York: Basic Books.

Gamertsfelder, Carl C. 1995. "Human Radiation Studies: Remembering the Early Years: Oral History of Health Physicist Carl C. Gamertsfelder, Ph.D.” https://ehss.energy. gov/ohre/roadmap/histories/0467/0467toc.html (accessed November 16, 2018).

Gerber, Michele Stenehjem. 1992. On the Home Front: The Cold War Legacy of the Hanford Nuclear Site. Lincoln, NE: University of Nebraska Press.

Geranios, Nicholas K. 2018. "Trump Plan to Reclassify Nuke Waste Alarms Environmentalist.” Associated Press, December 11. https://apnews.com/97808a157a10 477a9f89f51f0fd67954 (accessed December 21, 2018).

Government Accounting Office. 1993. "Nuclear Health and Safety: Examples of PostWorld War Two Radiation Releases at U.S. Nuclear Sites." Washington DC: United States Government Accounting Office.

Haerer, H. A., M. D. Freshley, R. O. Gilbert, L. G. Morgan, B. A. Napier, R. E. Rhoads, and R. K. Woodruff. 1990. Hanford Environmental Dose Reconstruction Project: Overview. Richland, WA: Pacific Northwest Laboratory.

Harvey, David. 2000. History of the Hanford Site, 1943-1990. Richland, WA: Pacific Northwest National Laboratory.

Hewlett, Richard G., and Oscar E. Anderson, Jr. 1962. The New World, 1939-1946: A History of the United States Atomic Energy Commission, Volume 1. Philadelphia: University of Pennsylvania Press.

Hoddeson, Lillian, Paul W. Henriksen, Roger A. Meade, and Catherine L. Westfall. 2004. Critical Assembly: A Technical History of Los Alamos during the Oppenheimer Years, 1943-1945. Cambridge: Cambridge University Press.

Ichikawa, Hiroshi. 2015. "Radiation Studies and the Soviet Scientists in the Second Half of the 1950's." Historia Scientiarum 25 (1): 78-93.

Jacobs, Robert. 2018. "The Visible and the Invisible when Considering Northern European Spent Permanent Spent Nuclear Fuel Storage." Hiroshima Peace Research Journal 5: 13-33.

Lanouette, William. 1992. Genius in the Shadows: A Biography of Leo Szilard, the Man Behind the Bomb. New York: Charles Scribner's Sons.

Makhijani, Arun, A. James Ruttenber, Ellen Kennedy, and Richard Clapp. 1995. "The United States." In Nuclear Wastelands: A Global Guide to Nuclear Weapons Production and Its Health and Environmental Consequences, eds. Arun Makhijani, Howard Hu, and Katherine Yu, 169-284. Cambridge, MA: MIT Press.

Nuclear Engineering Division. n.d. "History of Argonne reactor operations." Argonne National Laboratory. https://www.ne.anl.gov/About/reactors/History-of-ArgonneReactor-Operations.pdf (accessed November 15, 2018).

Pritikin, Trisha. Forthingcoming. The Plaintiffs: Hanford Downwind. Under review.

Rabl, Thomas. 2012. "The Nuclear Disaster of Kyshtym 1957 and the Politics of the Cold War." Arcadia 20. https://doi.org/10.5282/rcc/4967 (accessed November 15, 2018).

Sanger, S. L. 1989. Hanford and the Bomb: An Oral History of World War Two. Seattle: Living History Press.

Schneider, Keith. 1989. "Agreement Set for a Cleanup at Nuclear Site." New York Times, February 28. 
Simon, Steven L., and André Bouville. 2015. "Health Effects of Nuclear Weapons Testing." The Lancet 386 (9992): 407-409.

Smyth, Henry DeWolf. 1945. Atomic Energy for Military Purposes: The Official Report on the Development of the Atomic Bomb under the Auspices of the United States Government, 1940-1945. Princeton: Princeton University Press.

Technical Steering Panel of the Hanford Environmental Dose Reconstruction Project. 1992. “The Green Run.” Fact Sheet \#12. Technical Steering Panel, Oregon Dept. of Ecology, Nuclear \& Mixed Waste Management Program.

USDOE (United States Department of Energy). 2017. Site A/Plot M, Illinois, Decommissioned Reactor Site History. Washington DC: United States Department of Energy, Office of Legacy Management.

Robert (Bo) Jacobs is a historian of nuclear technologies and radiation technopolitics. He is a professor at the Hiroshima Peace Institute and Graduate School of Peace Studies of Hiroshima City University. He has published multiple books and articles, including: The dragon's tail: Americans face the atomic age (2010; Japanese translation, 2013), Filling the hole in the nuclear future: art and popular culture respond to the bomb (2010), Images of rupture in civilization between East and West: the iconography of Auschwitz and Hiroshima in Eastern European arts and media (2016), and Reimagining Hiroshima and Nagasaki: nuclear humanities in the post-Cold War (2017). Jacobs has conducted extensive fieldwork on the human and social impacts of nuclear technologies and radiation exposures. His recent work has also focused on the problems posed by the long-term storage of high level nuclear waste. He is a project leader of the Global Hibakusha Project, which works to link radiation-affected communities around the globe. 
